\title{
Electra korobokkura sp. n., a new species of cheilostome bryozoan from the Pacific coast of Hokkaido, Japan
}

\section{E.A. Nikulina}

\author{
Institut für Geowissenschaften der Christian-Albrechts Universität zu Kiel, Olshausenstr. 40, Kiel, \\ D-24118, Germany \\ Leibniz-Institut für Meereswissenschaften, Düsternbroocker Weg 20, Kiel, D-24105, Germany. \\ e-mail:en@gpi.uni-kiel.de
}

\begin{abstract}
A new species of cheilostome bryozoan of the genus Electra is described from the Pacific coast of Hokkaido, Japan. The species Electra korobokkura sp.n. can be distinguished from the closely related species $E$. arctica by colony morphology and zooid sizes. Zooids of E. korobokkura are distinctly smaller, and colonies comprise uniserial to narrow oligoserial chains; in E. arctica, colonies usually form compact fan-shaped patches. In the diagnosis, genetic data are included: partial sequences of the $18 \mathrm{~S}$ and $16 \mathrm{~S}$ rDNA. The data can be used for molecular identification of the species.
\end{abstract}

KEYWORDS: taxonomy, Electra, Cheilostomata, Bryozoa.

\section{Electra korobokkura sp. n. - новый вид хеилостомной мшанки с тихоокеанского побережья Хоккайдо, Япония}

\begin{abstract}
Е.А. Никулина
Геологический институт Христиан-Альбрехт Университета г. Киля, Германия Лейбнии институт морских наук, г. Киль, Германия.

e-mail: en@gpi.uni-kiel.de

РЕЗЮМЕ: Описан новый вид хейлостомной мшанки рода Electra с тихоокеанского побережья Хоккайдо, Япония. Electra korobokkura sp.n. отличается от похожего вида E. arctica размерами зооидов и формой колонии. Зооиды E. korobokkura заметно меньше, а колонии обычно состоят из разрозненных рядов зооидов; у $E$. arctica колонии представляют собой компактные веерообразные пласты. В диагнозе приведены генетические данные (нуклеотидные последовательности фрагментов $16 \mathrm{~S}$ и $18 \mathrm{~S}$ рибосомальных генов), которые могут быть использованы для молекулярной идентификации вида.
\end{abstract}

КЛЮЧЕВЫЕ СЛОВА: таксономия, Electra, Cheilostomata, Bryozoa.

\section{Introduction}

The genus Electra Lamouroux, 1816 is a member of the oldest cheilostome family Elec- tridae d 'Orbigny 1851 which first occurs in the Upper Jurassic (Pohowsky, 1973; Taylor, 1994). The morphology of recentElectra species share many features with the first bryozoans of the 
order Cheilostomata (Larwood, 1973, 1975; Taylor, 1986a; Taylor, Cuffey, 1992; Nikulina, 2002). The oldest known cheilostomes are $P y$ riporopsis pohowskyi Taylor, 1994 from the Oxfordian or Kimmeridgian of South Yemen and $P$. portlandensis Pohowsky, 1973 from the Tithonian of southern England. Colonies of these bryozoans are encrusting and comprise uniserial to pluriserial chains of simple ovoid or pyriform zooids with extensive oval opesia (Taylor, 1986b). A similar morphology is also characteristic of recent species of Electra. Their study has the potential to elucidate aspects of early cheilostome evolution. About seventeen recent and fossil species of Electra species have been described. Taxonomic description of an additional new species is presented here.

Bryozoan specimens were collected during the period of low tides in July 2003 in several localities in Akkeshi Bay, Hokkaido, from the mid to lower rocky and rocky-boulder intertidal zones, within the biocoenosis of laminarian algae. All colonies encrusted hard substrata of shell fragments or gravel. Genetic analyses of the material indicated the presence of two distinct species sharing the general morphotype of Electra arctica Powell, 1968 (Nikulina, in preparation). The two species are syntopic, inhabiting the same substrates and often overgrowing one another. A formal taxonomic description is given of the new species Electra korobokkura.

$$
\begin{aligned}
& \text { Order Cheilostomata Busk, } 1852 \\
& \text { Family Electidae Stach, } 1937 \\
& \text { Genus Electra Lamouroux, } 1816
\end{aligned}
$$

\section{Electra korobokkura sp.n.}

Holotype. Colony on a shell fragment in the collection of the Senckenberg Museum, Frankfurt, Germany, type number SMF 1723; genetic data: fragment $18 \mathrm{~S}$ rDNA, EMBL Accession number AM158086; fragment 16S mtDNA, EMBL Accession number AJ853948.

Paratype. Same data as for holotype, SMF 1724; genetic data: fragment 18S rDNA, EMBL Accession number AM158086; fragment 16S mtDNA, EMBL Accession number AJ853947.
Type locality. Akkeshi Bay, Pacific coast of Hokkaido, Japan.

Etymology. The name refers to the small size of the zooids. "Korobokkur" is an Ainu word meaning fabulous small creatures (Ainu are the indigenous people of Hokkaido).

Diagnosis. Zooids pyriform, small (length $0.55 \mathrm{~mm}$, width $0.30 \mathrm{~mm}$ ), 1:1 ratio of opesia to gymnocyst length, cryptocyst narrow, a tiny medial-proximal spine present in some zooids, operculum calcified. Colonies encrusting, usually uniserial or oligoserial.

\section{Description}

E. korobokkura forms encrusting colonies that are intensively calcified and white in appearance. Colonies are uniserial or irregularly oligoserial, growing on hard substrates (Fig. 1).

Zooids are elongate pyriform to ovoidal and approximately $0.55 \times 0.30 \mathrm{~mm}$ in size, with an oval membranous frontal area occupying about one half of the frontal surface (Figs. 2, 3). Gymnocyst is smooth, imperforate, and is marked with annulations. Opesia is completely surrounded by a narrow mural rim and a narrow cryptocyst, the latter consisting of a minutely tuberculate outer part and a smooth inner part more developed proximally (Fig. 2). There is usually one very fine and small proximal median spine with a chitinous tip. This projects from the distal gymnocyst obliquely forwards over the opesia and seldom extends more than one fifth of opesial length. The base of the spine is calcified and forms a small boss on the gymnocyst. In many zooids the spine is absent. Operculum is calcified, thumbnail-like in shape and with a straight transverse proximal border (Fig. 3A, B). Basal wall is usually completely calcified, but in some zooids a central irregular uncalcified area is present.

Closure plates contain one central pore (Figs. 24). Closed buds develop kenozooids (Fig. 4). Ancestrula and pattern of early colony development are unknown.

Measurements. Zooid length: range $=0.31-0.67$ $\mathrm{mm}$; zooid width: range $=0.25-0.39 \mathrm{~mm}$; opesia length: range $=0.26-0.35 \mathrm{~mm}$; opesia width: range $=$ $0.12-0.19 \mathrm{~mm}$; operculum length: range $=0.08-0.09$ $\mathrm{mm}$.

Remarks. E. korobokkura could be confused with E. arctica Powell, 1968, E. crustulenta (Pallas, 1766), and Pyripora catenularia (Fleming, 1828). There are clear differences between $P$. catenularia and E. korobokkura. The first species never possess spines and calcareous opercula that are characteristic of $E$. 


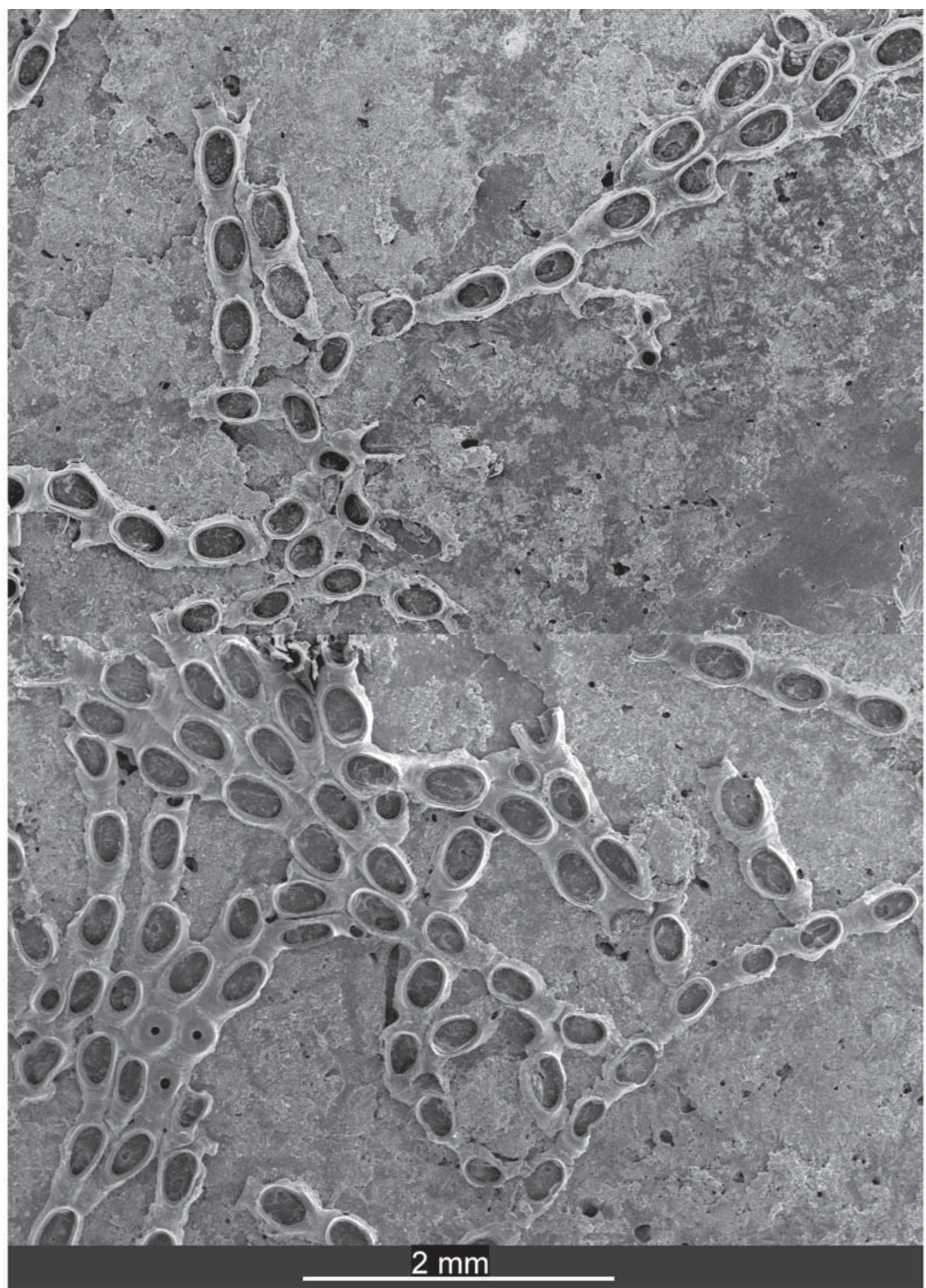

Fig.1. Electra korobokkura sp.n., colony morphology. Holotype, SMF 1723.

Рис.1. Electra korobokkura sp.n., общий вид колонии. Голотип, SMF 1723. 


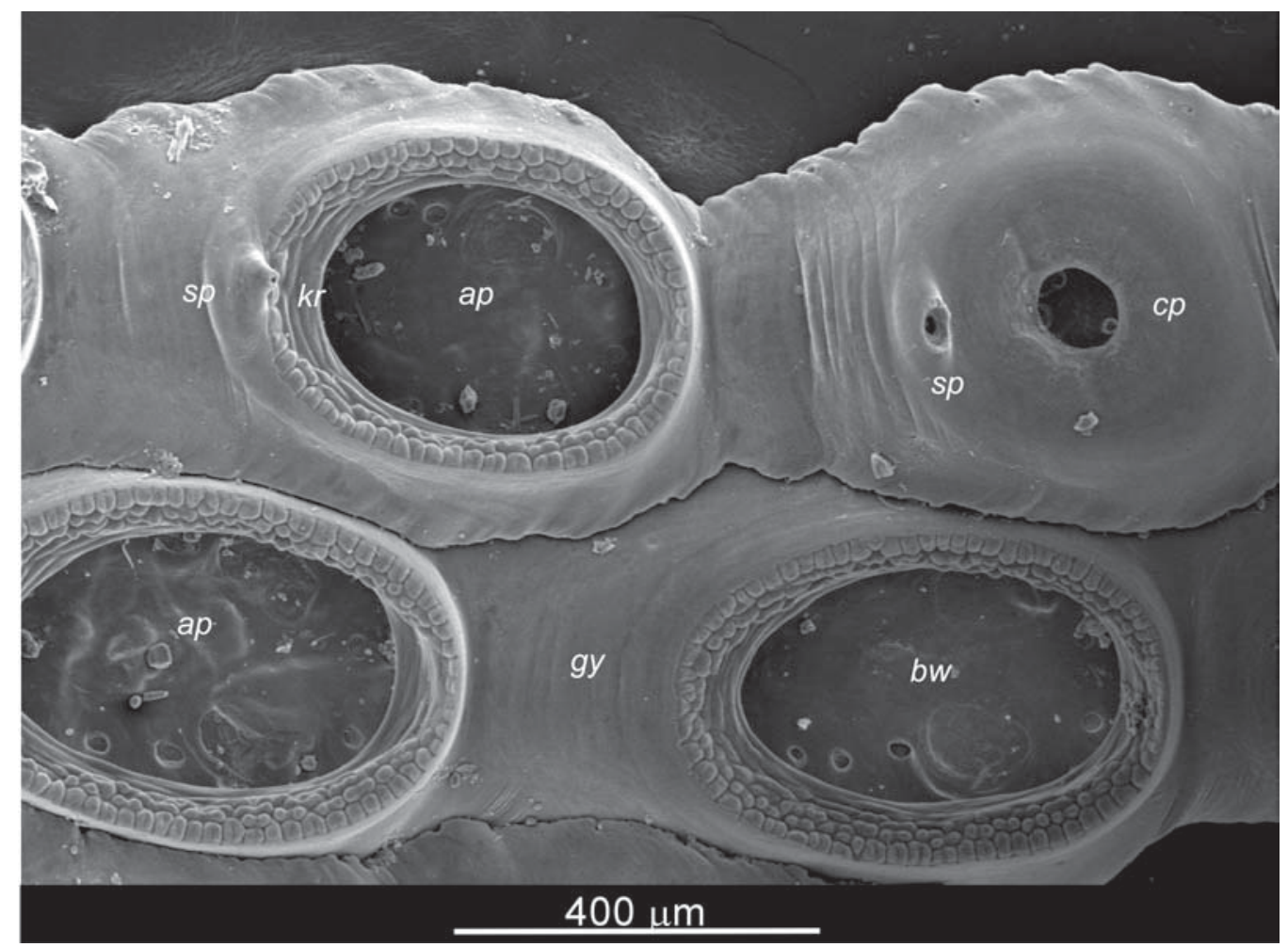

Fig.2. Electra korobokkura sp.n., details of zooidal skeletons. Paratype, SMF 1724.

Gymnocyst (gy), cryptocyst (kr), opesia (ap), basal wall (bw), spine (sp), closure plate (cp).

Рис.2. Electra korobokkura sp.n., скелеты зооидов. Паратип, SMF 1724.

Гимноцист (gy), криптоцист (kr), опезия (ap), базальная стенка (bw), шип (sp), «закрывающая пластинка» (cp).

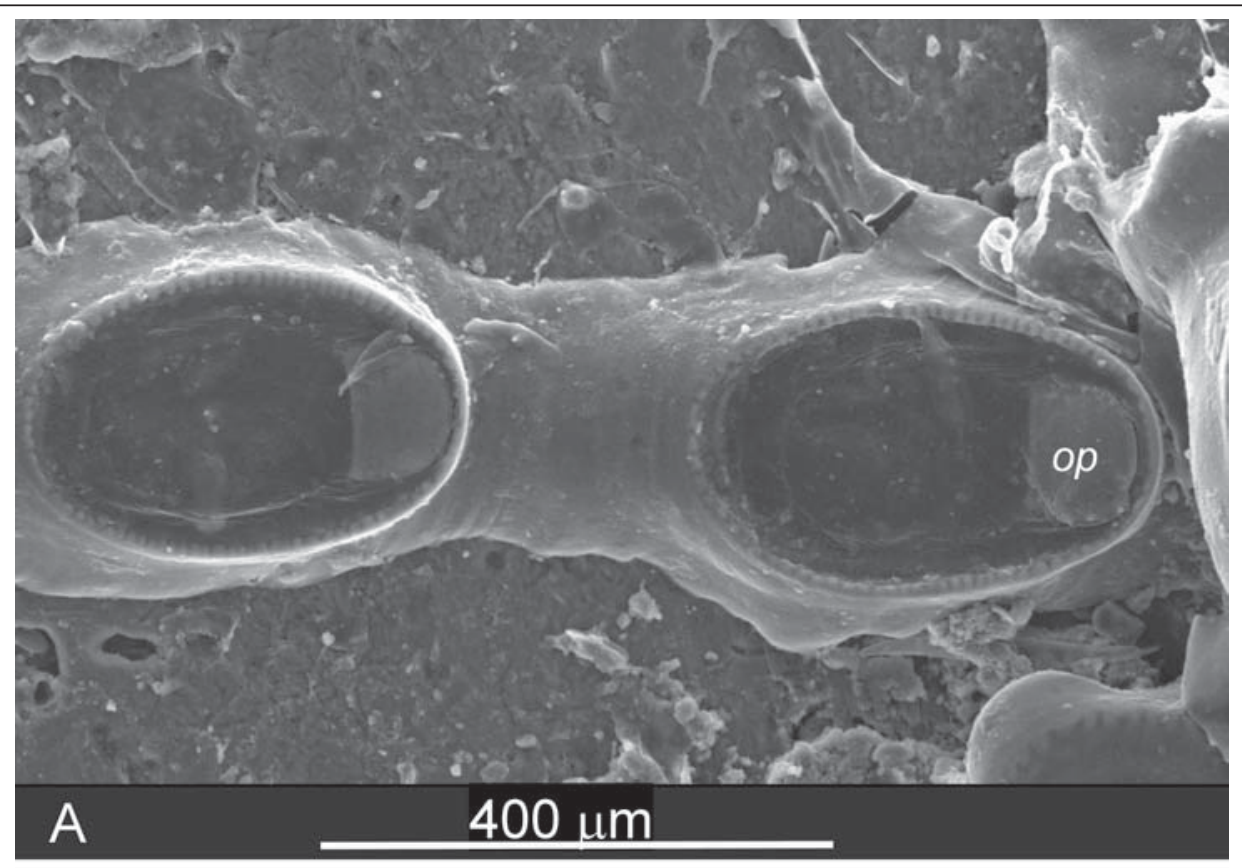



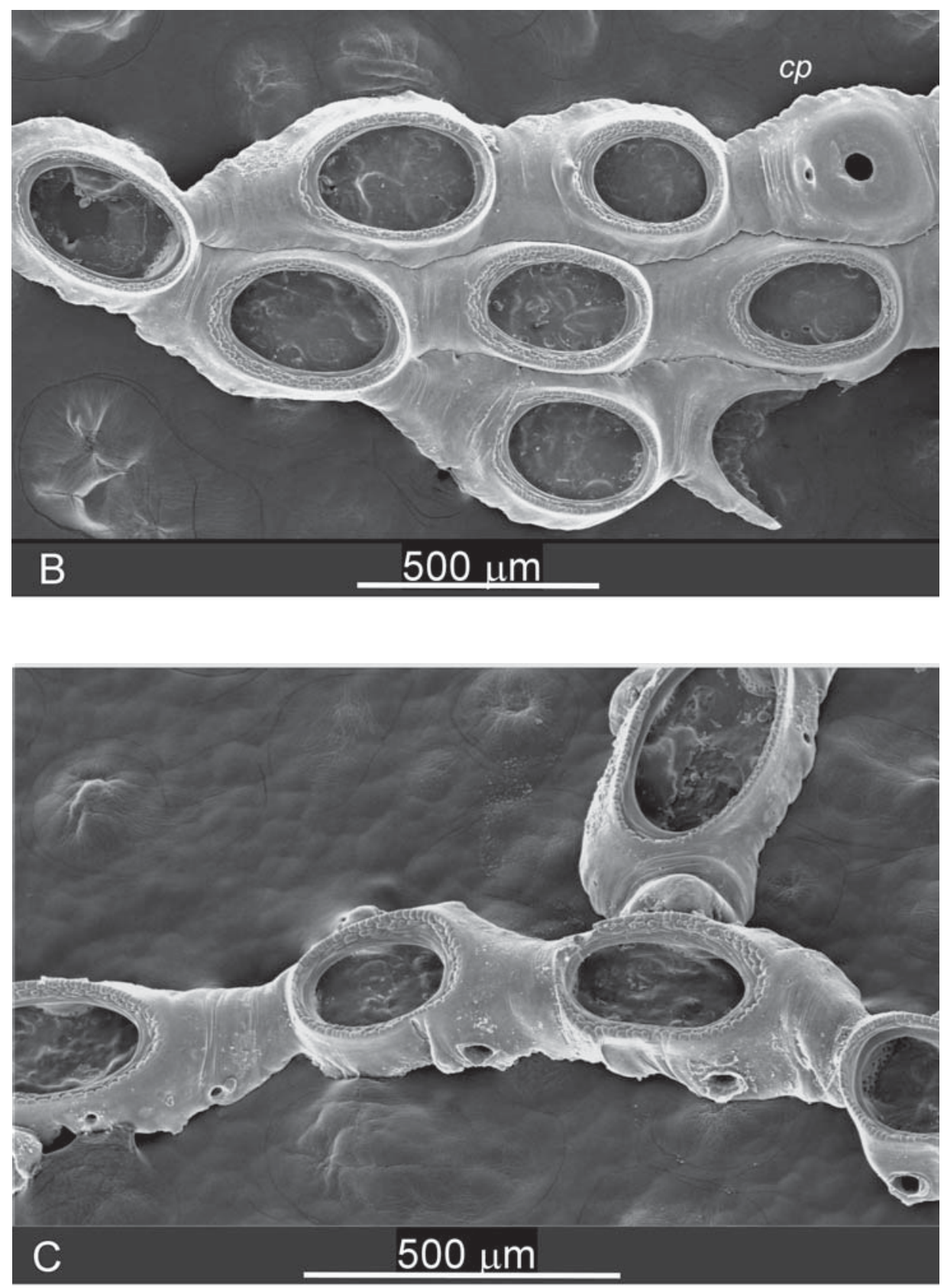

Fig.3. Electra korobokkura sp.n., details of zooid morphology. Holotype, SMF 1723.

A - zooids with intact frontal membranes (fm) and opercula (op). B-C - skeletons.

Рис.3. Electra korobokkura sp.n., особенности строения зооидов. Паратип, SMF 1724.

A - зооиды с сохранившейся фронтальной мембраной (fm) и оперкулумом (op). В-C - скелетированные зооиды. 
Tabl. 1. Morphological comparison between $E$. korobokkura sp.n. and E. arctica Powell, 1968. Mean, range, standard error of the mean, standard deviation (square root of variance) for each morphometric character are presented. Number of measurements is 50. P-values calculated on the basis of Mann-Whitney U test demonstrate statistical significance of differences in medians of the estimates between the two compared species.

Табл. 1. Морфологические различия между $E$. korobokkura sp.n. и E. arctica Powell, 1968.

Приведены среднее (арифметическое), размах, стандартная ошибка среднего, стандартное отклонение от среднего (квадратный корень из дисперсии) кля каждого морфометрического признака. Число измерений равняется 50.

Значение P, расчитанное на основе Mann-Whitney U теста, отражает статистическую достоверность различий между медианами измерений для этих двух видов. Число измерений равняется 50.

korobokkura. Zooids of E. crustulenta although have calcareous opercula and spines, but their gymnocysts are almost completely reduced. Moreover, colonies of E. crustulenta are usually multiserial sheets; such colony morphology was not found in E. korobokkura. E. arctica is morphologically the most similar species to $E$. korobokkura (Fig. 5) and it is relatively difficult to discriminate between them. An important distinction is the size of zooids, which are significantly smaller in E. korobokkura (Tab.1, Fig. 5). Spines are rarer and smaller in E. korobokkura than in E. arctica. In colony morphology there are also differences. Colonies are usually uniserial and oligoserial in E. korobokku$r a$, and oligoserial to multiserial, developing compact fan-shaped patches in E. arctica.

\section{Acknowledgments}

I am indebted to Professor Shunsuke F. Mawatari for providing research facilities at the Laboratory of the Systematic and Evolution (Hokkaido University, Japan) and to the staff of laboratory for assistance with many aspects of this work, particularly Dr. Norio Kabayashi and Dr. Yoshinobu Nodasaka. I am grateful to Dr.

\begin{tabular}{|c|c|c|}
\hline & E. korobokkura & E. arctica \\
\hline Colony morphology & $\begin{array}{r}\text { uniserial or } \\
\text { oligoserial }\end{array}$ & $\begin{array}{c}\text { oligoserial or } \\
\text { multiserial }\end{array}$ \\
\hline Zooid form & pyriform & $\begin{array}{c}\text { pyriform or } \\
\text { oval }\end{array}$ \\
\hline \multicolumn{3}{|l|}{ Zooid length (mm) } \\
\hline Mean & 0.55 & 0.67 \\
\hline Range min-max & $0.31-0.67$ & $0.58-0.79$ \\
\hline Std. error & 0.012 & 0.009 \\
\hline Std. deviation & 0.09 & 0.004 \\
\hline $\mathrm{P}$-value & \multicolumn{2}{|c|}{$1.03 \mathrm{e}-10$} \\
\hline \multicolumn{3}{|l|}{ Zooid width (mm) } \\
\hline Mean & 0.30 & 0.38 \\
\hline Range min-max & $0.25-0.39$ & $0.32-0.42$ \\
\hline Std. error & 0.008 & 0.005 \\
\hline Std. deviation & 0.001 & 0.001 \\
\hline P-value & \multicolumn{2}{|c|}{$1.68 \mathrm{e}-13$} \\
\hline \multicolumn{3}{|l|}{$\begin{array}{l}\text { Opesia length } \\
(\mathrm{mm})\end{array}$} \\
\hline Mean & 0.32 & 0.43 \\
\hline Range min-max & $0.26-0.35$ & $0.34-0.50$ \\
\hline Std. error & 0.017 & 0.012 \\
\hline Std. deviation & 0.02 & 0.04 \\
\hline P-value & \multicolumn{2}{|c|}{$2.08 \mathrm{e}-16$} \\
\hline \multicolumn{3}{|l|}{$\begin{array}{l}\text { Operculum length } \\
(\mathrm{mm})\end{array}$} \\
\hline Mean & 0.08 & 0.12 \\
\hline Range min-max & $0.08-0.09$ & $0.11-0.13$ \\
\hline Std. error & 0.001 & 0.001 \\
\hline Std. deviation & 0.006 & 0.01 \\
\hline P-value & \multicolumn{2}{|c|}{$7.07 \mathrm{e}-18$} \\
\hline
\end{tabular}

Matthew Dick and Mr. Andrej Grichtchenko for prividing the material, and Dr. Wataru Abe (Chiba University, Japan) for proposing the name of the new bryozoan species. I acknowledge a 21 st Century Center of Excellence (COE) grant by the Japanese Ministry of Education, 


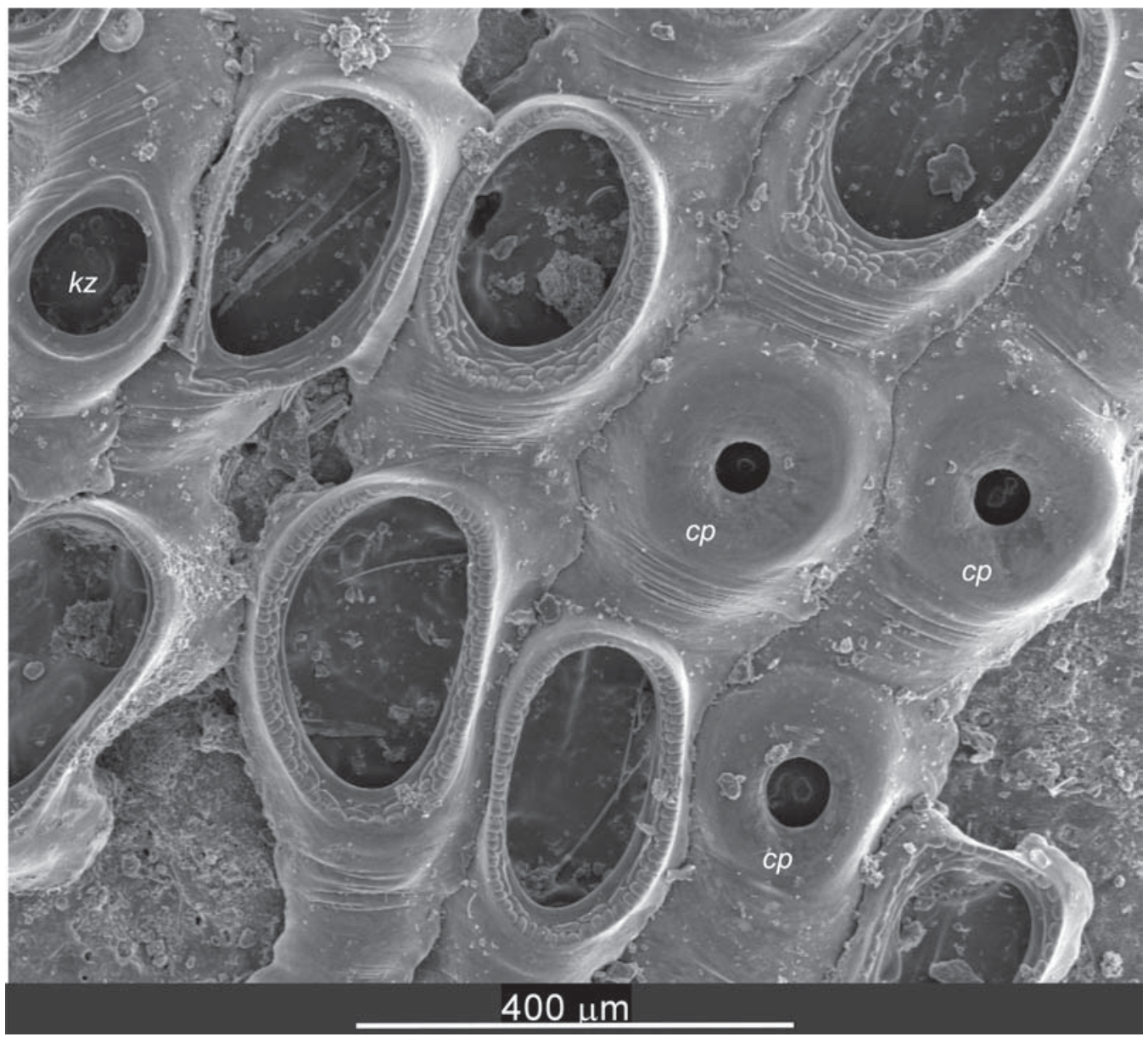

Fig.4. Electra korobokkura sp.n. Holotype, SMF 1723.

Closure plates (cp) and a kenozooid (kz).

Fig.4. Electra korobokkura sp.n. Голотип, SMF 1723.

“Закрывающая пластинка” (cp) и кенозооид (kz).

Culture, Sports, Science and Technology for the "Neo-Science of Natural History" Program (Leader: Hisatake Okada) at Hokkaido University, Japan. This work was partially founded by DFG (Germany) research grant Scha355/26I.

\section{References}

Larwood G.P. 1973. New species of Pyropora d'Orbigny from the Cretaceaous and the Miocene // G. P. Larwood (ed.). Living and Fossil Bryozoa - Recent Advances in Research. New York and London: Academic Press. P.463-474.
Larwood G.P. 1975. Preliminary report on Early (preCenomanian) cheilostome Bryozoa // S. Pouyet (ed.). Bryozoa 1974 - Proceedings of the 3rd International Bryozoology Association Conference. Documents des Laboratoires de Géologie de Lyon, H. S. Fasc. 2. P.539-545.

Nikulina E.A. 2002. The evolution of colony morphogenesis in bryozoans of the order Chilostomata // Paleontological Journal. Suppl.4. P.353-428.

Pohowsky R.A. 1973. A Jurassic Cheilostome from England // Living and Fossil Bryozoa: Recent Advances in Research. London, Acad. Press. P.447-461.

Taylor P.D. 1986a. Charixa Lang and Spinicharixa gen. nov., cheilostome bryozoans from the Lower Cretaceous // Bulletin of The Natural History Museum. Geology Series. Vol.40. No.4. P.197-222. 

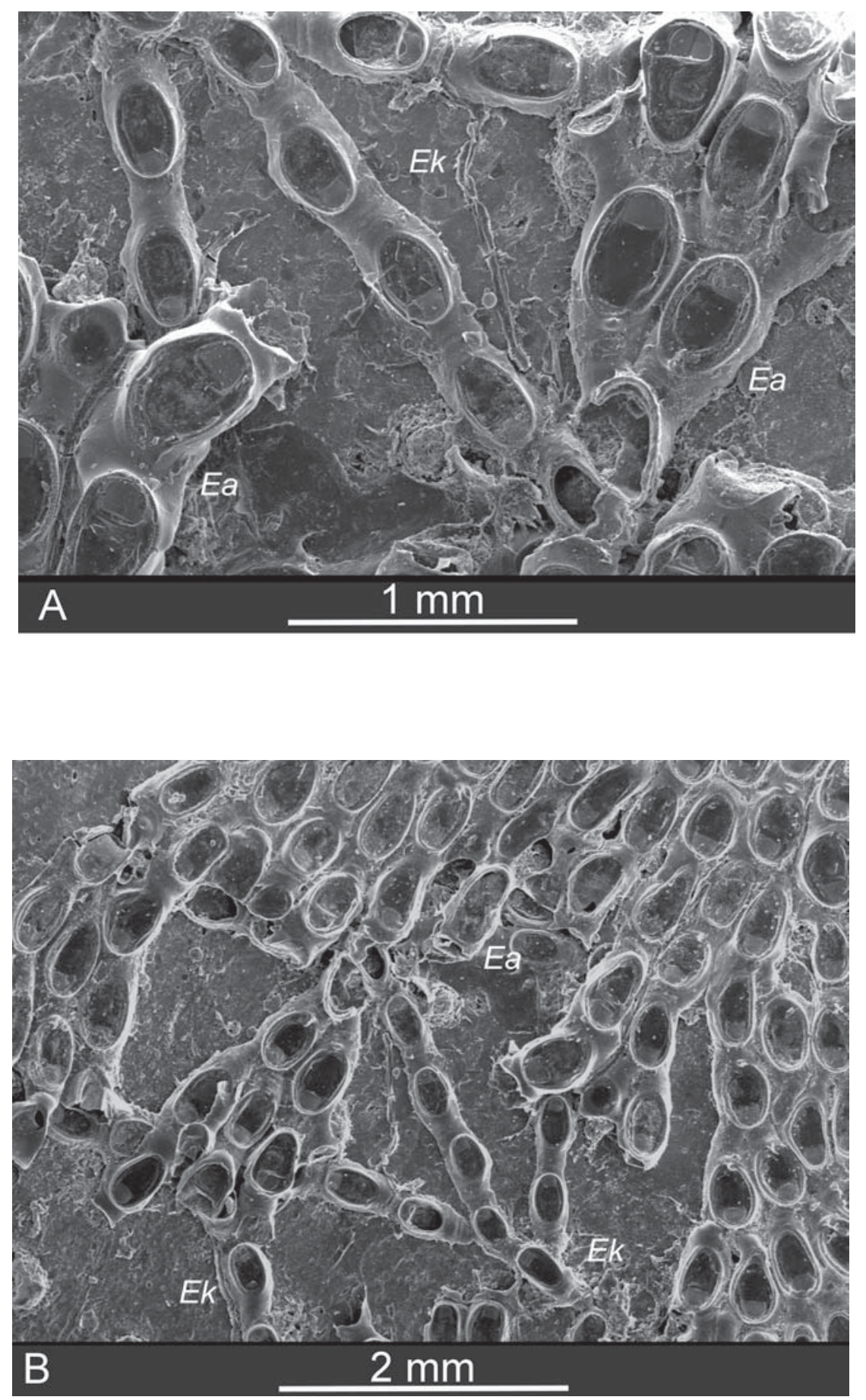


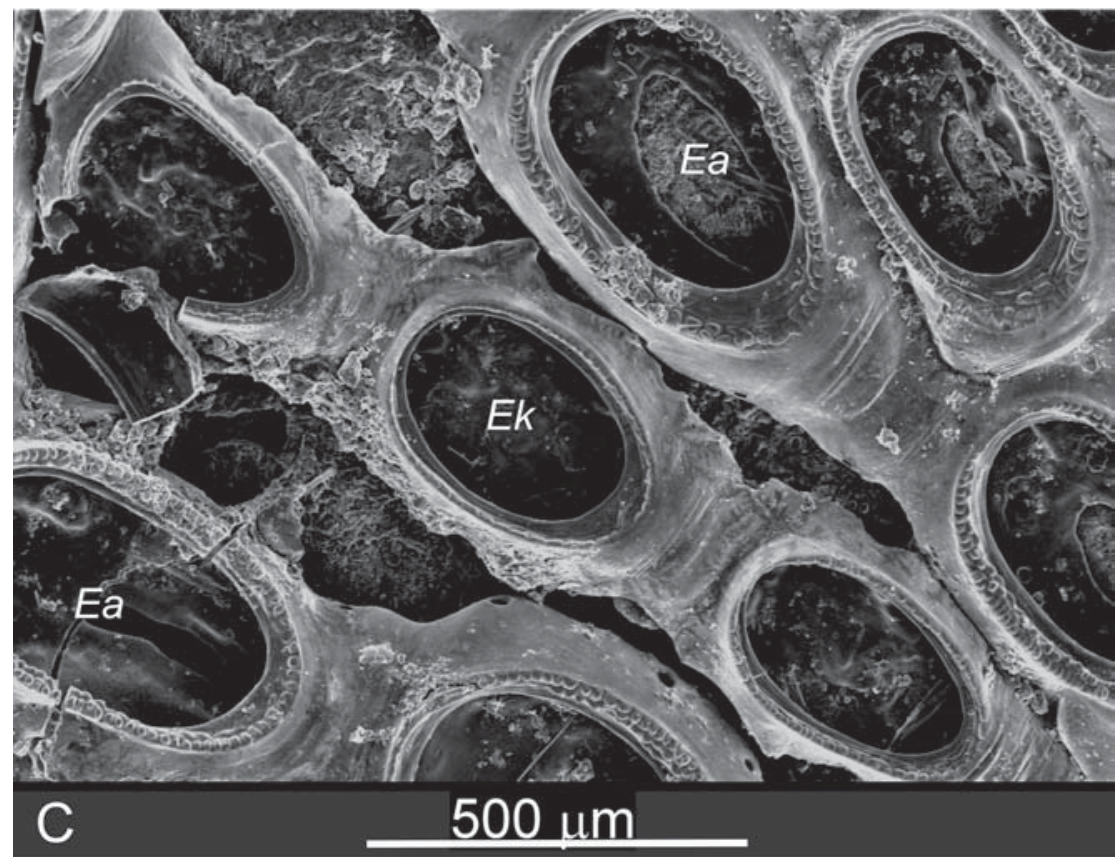

Fig.5. Electra korobokkura sp.n. (Ek) and E. $\operatorname{arctica}(\mathrm{Ea})$ from the Akkeshi Bay. A-C - Holotype, SMF 1723. Fig.5. Electra korobokkura sp.n. (Ek) и E. arctica (Ea) из бухты Аккеши. А-C — голотип, SMF 1723.

Taylor P.D. 1986b. The ancestrula and early growth pattern in two primitive cheilostome cheilostome bryozoans: Pyripora catenularia (Fleming) and Pyriporopsis portlandensis Pohowsky // Journal of Natural History. Vol.20. P.101-110.

Taylor P.D. 1994. An Early Cheilostome Bryozoan from the Upper Jurassic of Yemen // Neues Jahrbuch für
Geologie und Paläontologie. Abhandlungen. Vol.191. No.3. P.331-344.

Taylor P.D., Cuffey R.J. 1992. Cheilostome bryozoans from Upper Cretaceous of the Drummheller area, Alberta, Canada // Bulletin of The Natural History Museum. Geology Series. Vol.48. No.1. P.13-24. 


\title{
Книги Товарищества научных изданий КМК
}

\author{
Биология \\ Серия "Современная отечественная биология» \\ Избранные труды. В.В. Кучерук. 2006. 523 с. с портр. Формат 170 х 240 мм. Тв. перепл. \\ - Цена 250 руб. - Избранные труды. Е.Н. Матюшкин. 2005. 658 с. с портр. Формат 170 \\ х 240 мм. Тв. перепл. - Цена 300 руб. - Избранные труды по эволюционной биологии. \\ А.П. Расницын. 2005. iv + 347 с. с портр., 16 фототаблиц. Формат 170 х 240 мм. Тв. перепл. \\ - Цена 200 руб. - Избранные труды. Организм, геном, язык. Б.М. Медников. 2005. 452 \\ с. с портр. Формат 170 × 240 мм. Тв. перепл. - Цена 220 руб. \\ Также планируется: С.М. Разумовский. Избранные труды.
}

\section{Научно-популярные издания}

Киты и история китобойного промысла: взгляд из Японии. М. Комацу, С. Мисаки. 2005. 142 с., в тв. перепл., цв. вкл. Формат 145 х 215 мм. - Цена 150 руб.

\section{Справочные издания}

Биоклиматический потенциал России: теория и практика. А.В. Гордеев и др. 2006. 512 с., с цв. вкл., в тв. перепл. Формат 170 х 240 мм. - Цена 400 руб. - Конспект фауны земноводных и пресмыкающихся России. С.Л. Кузьмин, Д.В. Семенов. 2006. 139 с., в тв. перепл. Формат 145 x 210 мм. - Цена 150 руб. - Список птиц Российской Федерации. Е.А. Коблик и др. 2006. 281 с., бум. мелов., печать двухцветная, в обл. Формат 145 х 215 мм. - Цена 200 руб. - Биологический факультет МГУ. А.И. Нетрусов и др. (ред.). 2005. 242 с., в тв. перепл. Формат 170 × 240 мм. - Цена 180 руб. - Эволюционные факторы формирования разнообразия животного мира. Э.И. Воробьева, Б.Р. Стриганова (ред.). 2005. 308 с., в тв. перепл. Формат 170 × 240 мм. - Цена 150 руб. - Каталог моллюсков России и сопредельных стран. Ю.И. Кантор, А.В. Сысоев. 2005. 627 с., в тв. перепл. Формат 170 х 240 мм. - Цена 300 руб. - Каталог бесчелюстных и рыб пресных и солоноватых вод России с номенклатурными и таксономическими комментариями. Н.Г. Богуцкая, А.М. Насека. 2004. 389 с. с вложенным лазерным диском. Формат 170 x 240 мм. Тв. перепл. - Цена 200 руб. - Фундаментальные зоологические исследования. Теория и методы. А.Ф. Алимов, С.Д. Степаньяни (ред.). 2004. 318 с., в тв. перепл. Формат 170 х 240 мм. - Цена 150 руб. - Каталог типовых образцов сосудистых растений Восточной Азии, хранящихся в Гербарии Ботанического института им. В.Л. Комарова (LE). часть 1 (Япония и Корея). В.И. Грубов (ред.). 2004. 188 с., ил. Формат 140 x 205 мм. В обл. - Цена 80 руб. - Международный кодекс зоологической номенклатуры. Изд. 4е. 2-е изд. русск. пер. 2004. 223 с. Формат 143 х 213 мм. - Цена 70 руб. - Биология гидротермальных систем. А.В. Гебрук (ред.). 2002. 543 с. с цв. вкл., в тв. перепл. Формат 210 × 260 мм. - Цена 300 руб.

Также планируется: Г.Ю. Любарский. Эволюция зоологии. История одного музея. - Ю.И. Кантор, А.В. Сысоев. Морские и солоноватоводные брюхоногие моллюски России и сопредельных стран: иллюстрированный каталог (в печати).

\section{Научные монографии (начало)}

Эволюция биосферы и биоразнообразия. К 70-летию А.Ю. Розанова. С.В. Рожнов (отв. ред.). 2006. 600 с. с портр. Формат 170 × 240 мм. Тв. перепл. - Цена 300 руб. -Динамика и устойчивость рекреационных лесов. Л.П. Рысин и др. 2006. 165 с., цв. вкл. Формат 170 х 240 мм. Тв. перепл. - Цена 150 руб. - Флора субарктических гор Евразии и высотное распределение её видов. В.Б. Куваев. 2006. 568 с., ч/б вкл. Формат 170 х 245 мм. Тв. перепл. - Цена 280 руб. — Экологическая энергетика животных. Н.Д. Озернюк. 2006. 168 с. Формат 148 × 218 мм. Тв. перепл. - Цена 150 руб.

Для заявок: см. стр. 52 этого журнала 